\title{
Arguing from Experience: Travelees versus Travelers in Early Modern Exchanges
}

\author{
WENDY BRACEWELL
}

In 1768 Giuseppe Baretti, an Italian writer and critic resident in London, published a book in English, written to dispute the views of Italy and the Italians circulated by British travelers returning from the Grand Tour. ${ }^{1}$ Baretti gave as his central example an English surgeon, Dr Samuel Sharp, who had recently published a volume of Letters from Italy (London, 1766). Baretti's attack singled out the errors and exaggerations found in this and other such accounts, but also drew attention to the dubious methods by which travel experience was converted into knowledge, particularly the branch of knowledge that dealt with the character of nations:

\begin{abstract}
Would an Italian surgeon, perfectly ignorant of the English language, be entitled to any credit if, after a few months' residence in England, he took into his head to give, in a printed book, the character of the English nobility, or even of the English cobblers? I, who have resided many years in England; who have visited the greatest part of its provinces; who am tolerably skilled in its language, and have kept a great variety of English company, would find myself much embarrassed, was I to give an account of the manners of any class of people in this kingdom. I know that such a task is very difficult to a foreigner; and that, even after a long study of any people, we are liable to mistakes. I should, therefore, feel the greatest diffidence, and think myself obliged to speak with the greatest caution, if ever I could prevail upon myself, to make such an attempt, especially where I found myself disposed to condemn any general or reigning custom, to censure a whole sex, a whole profession, or any entire body of people (Baretti, Account, Vol. 1, 10-11).
\end{abstract}

Even a well-informed and well-intentioned foreigner could be prone to error and incomplete knowledge. Why should readers accept the conclusions of an observer whose travels were cursory, whose encounters were limited by social status as well as by ignorance of the language, and whose sweeping criticisms were based on a limited sample? Baretti implies that his readers would

\footnotetext{
${ }^{1}$ Joseph Baretti, An Account of the Manners and Customs of Italy, with Observations on the Mistakes of some Travelers, with regard to that Country (London, 1768).
} 
scoff at the notion of an Italian traveler pronouncing on the English. Was their willingness to believe accounts by their own ill-equipped travelers grounded in nothing more than cultural affinity? Or should all representations of experience, and the knowledge based on them, be judged by the same criteria?

Baretti was not the only critic to challenge the assessments of his own country published by foreign travelers. Early modern travel writers very rarely seem to consider that their narratives might be read by the people that they travelled among and wrote about - the 'travelees', to use Mary Louise Pratt's awkward but useful coinage. ${ }^{2}$ However, published travel accounts circulated well beyond their implied domestic audiences. From the sixteenth century onwards, many educated Europeans acquired and read foreign travel accounts about their own societies with considerable interest. Of these, a surprising number not only took issue with the views they found there but went so far as to publish rebuttals, challenging the travelers' claims as erroneous, and in particular contradicting characterizations of their societies as different in any fundamental way from the travelers' own homelands.

What was at issue in these travelee polemics? While each case had its own context and purpose, such debates shared key preoccupations with questions of truth, credibility, and authority. Indignant travelees disputed not only the details of foreign accounts, but also the ways in which the travelers had reached their conclusions. From the perspective of those who were represented, travel experience and direct observation, even when accurately reported, were not always a sound basis for knowledge. The travelees' criticisms, and the responses of those they attacked, give an insight into the social and cultural construction of early modern ethnographic truth. Whose experience counted, in whose eyes?

A survey of the geographical scope of early modern travelee polemics would show readers from almost every corner of Europe (and sometimes beyond) reacting to travelers' depictions and penning exasperated replies, with the density of the exchanges tied to the degree of connection to the wider European intellectual and political sphere. While the specific details at issue varied, it is possible to trace increasingly frequent clashes over the 'character' of a nation from the sixteenth into the eighteenth century. Travelees published attacks addressed to transnational audiences and both travelers and other combatants replied, reviewed, and recirculated the debates. While these disputes have rarely been studied outside their specific national contexts, they deserve attention as a general phenomenon - not least for the light they can throw on attitudes to the relationship between travel experience and travel knowledge. ${ }^{3}$

\footnotetext{
${ }^{2}$ Mary Louise Pratt, Imperial Eyes: Travel Writing and Transculturation (London: Routledge, 1992), 7, 242.

${ }^{3}$ For a general survey, see Wendy Bracewell, 'The Travellee's Eye: Reading European Travel Writing, 17501850', in Julia Kuehn and Paul Smethurst (eds.), New Directions in Travel Writing Studies (London: Palgrave Macmillan, 2015), 215-27.
} 
Here, a selection of examples highlights some of the objections, strategies and problems associated with travelee polemics. They come from a variety of places across Europe: Iceland, Ireland, Italy, Dalmatia and Spain. While they stretch from the sixteenth to the eighteenth centuries, they are all preoccupied with representations of cultural or civilizational difference, and the way that print technology spread and perpetuated (mis)representations. The chronological spread, however, also foregrounds some differences, notably those deriving from characteristics of the travel genre, whether the compilations of cosmographers or historians and the vernacular travel poems of the sixteenth century or the 'manners and customs' narratives and more subjective pre-Romantic travels of the eighteenth century. Each of these demanded specific travelee strategies to craft an effective response.

The earliest case of polemic treated here is the Brevis commentarius de Islandia, published in Copenhagen in 1593 by an Icelander, Arngrímur Jónsson, who wrote at the instigation of his uncle Gudbrandur Thorláksson, Bishop of Hólar. ${ }^{4}$ The bishop's preface to the work sums up the case: foreign writings were 'causing an innocent nation to be had in derision by others'. At the top of his list was a defamatory German travel poem about Iceland by a Hamburg merchant, Gories Peerse, although it was in fact his publisher whom Gudbrandur denounced most vehemently, since the multiple reprints of the poem had subjected Iceland to 'shameful and everlasting ignominy'. He then turned his ire on scholarly compilers who eagerly capitalized on travelers' hearsay, and those who plagiarized and spread these falsehoods. The bishop emphasized that Arngrímur did not write from vanity or hope of profit, but had agreed to defend Iceland solely from his love of country; in doing so he relied on 'his own experience, and many other men's also of sufficient credit'. In short, Icelanders resented the opprobrium they were subject to as a result of false information spread abroad out of venality, gullibility or laziness, and then fixed in print. Their response was authorized by patriotic obligation, and their counter-claims validated by first-hand observation or testimony from reliable witnesses.

Arngrimur then elaborated all these points at length. He stresses due decorum, underlining his reluctance to put himself forward and his efforts to moderate his righteous anger in defense of his patria. Decorum also colours his claim to differentiate appropriately between common travelers and the learned cosmographers and historians who had dealt with Iceland, including

\footnotetext{
${ }^{4}$ Arngrímur Jónsson, Brevis commentarius de Islandia (Hafniae, 1593); reprinted and translated in Richard Hakluyt (ed.), The Principal Navigations, Voyages, Traffiques and Discoveries of the English Nation (London, 15991600), I, 550-91; cited from this edition with the English revised according to modern usage. See also Wilhelm Seelman, 'Gories Peerse's Gedicht van Island', Jahrbuch des Vereins für niederdeutsche Sprachforschung, 9 (1883), 110-25, and more generally on Arngrímur, Jakob Benediktsson, Arngrimur Jónsson and his Works (Copenhagen: Ejnar Munksgaard, 1957).

${ }^{5}$ Gudbrandur Thorláksson, in Principal Navigations, 552.
} 
Sebastian Münster, Gemma Frisius, Jacob Ziegler, and Albert Krantz. The scholars deserve respect: though too ready to believe 'impossible \& ridiculous things' they are not deliberate slanderers. ${ }^{6}$ He reserves harsher treatment for the sailors who provided their information, and above all the German 'vagabond huckster' Peerse, not only because of their low social status (which to Arngrímur implies their untrustworthiness) but also for their deliberate malice and crudity. ${ }^{7}$ Ultimately however, Peerse serves as a pretext to take on the ostensibly more authoritative scholars. From chapter to chapter, the Icelander demonstrates that they too have been negligent, self-promoting, and un-Christian. All have defamed Iceland in order 'that they may be accompted superiors': their slanders against Iceland were intended to establish personal and civilizational hierarchies that worked to their own advantage. ${ }^{8}$

Both the versifier and the scholars had given overviews of what Peerse divided into 'the nature and character of Iceland' and 'the capacities of its people'. Arngrímur's response mirrored this conventional chorographic organization of knowledge, with a section on the island followed by a second on its inhabitants, each addressing charges cited from his opponents. What was at issue for Arngrímur were characterizations of Iceland as existing outside the laws of nature and man. He particularly objected to the cosmographers' readiness to see Iceland as the location of supernatural wonders - the mouth of Hell in a volcano, a prison of damned souls in the ice - which led to it being unjustly abominated, since 'there is nothing in all the world more base, \& worthless than it, which containeth hell within the bounds therof'. ${ }^{10}$ He decried the double standards that led scholars to describe Iceland's volcanoes in fantastical terms but to seek natural causes for eruptions of Mt Etna. Citing reformed theology on the destiny of souls (and reminding readers that his nation was both spiritually and geographically part of the European community), the Icelandic parson stated that 'We hold that Icelanders are no whit nearer [to Hell] in regard of the situation of place, than the Germans, Danes, Frenchmen, Italians, or any other nation whatsoever'. ${ }^{11}$ Such comparisons served to normalize Iceland: distant and unknown, but not supernatural or inexplicable.

Arngrímur also denounced claims about the Icelanders' inhuman, immoral, or perverse customs: that they loved their dogs more than their children, did not recognize adultery as a sin, had filthy habits and disgusting food, were inhospitable, and so on. While denying the worst slanders, he again underlined the double standards that characterized such judgments, referring to

\footnotetext{
${ }^{6}$ Arngrímur, in Principal Navigations, 570.

7 Ibid., 586.

${ }^{8}$ Ibid., 552.

${ }^{9}$ Seelman, op. cit., 121. On humanist 'methodizing' of travel knowledge see Justin Stagl, A History of Curiosity: The Theory of Travel 1550-1800 (Chur: Harwood Academic, 1995), especially 57-65.

${ }^{10}$ Arngrímur, in Principal Navigations, 562.

11 Ibid., 563.
} 
foreign noblewomen carrying dogs in their bosoms, or parents driven by famine to sell or kill their children in Hungary, not just in Iceland. But even more forcefully, he argued that the travelers' testimony could not be trusted, for the witnesses were not only malicious and lacking social credit - they were also the victims of jokes or fraud; they generalized their encounters with single individuals or with the very basest sort of people to the whole Icelandic nation; and they distrusted anything unfamiliar.

What 'they say' is opposed to what 'we hold' throughout these arguments. Arngrímur pointed to the arrogance of those who imagine they can teach others about a language they don't know, holding up to scorn those who prefer to mangle placenames, rather than 'learn of the Icelanders themselves'. ${ }^{12}$ While the humanist Arngrímur cited classical authorities - Aristotle, Pliny, Strabo - in support of his arguments, he also used Icelandic chronicles, asking his distant readers whether they should not trust local historical sources for 'our own particular \& domestic affairs, done within the bounds of our Iceland' rather than the claims of a foreign historian. ${ }^{13}$ The very character of these local sources lent them authority: not only were they the written records of a literate, self-conscious (and pointedly Protestant) culture, they were reliable because produced for pragmatic domestic use, not for any polemical purpose. The assumption throughout is that 'we', the Icelanders, hold greater authority than foreigners. But simply being local wasn't enough - thus Arngrímur repeatedly validated his personal observations with appeals to other sources of authority, not only classical learning and Icelandic sources but piety, logic and natural philosophy. Nor did locals have a monopoly on authoritative statements about Iceland. Arngrímur cited approvingly 'the experience of many strangers who have lived some years among us, and have more mind to speak the truth than to revile our nation; who have seen our house and habitations with their own eyes'. ${ }^{14}$ In practice he conceded the greater authority to foreigners who spoke well of Iceland since their reported experience required no additional validation in his text. It is a paradox he does not seem to notice.

Arngrímur's task was not to provide a new, more accurate account of Iceland; he presented himself as neither a historian nor a geographer, but 'only a disputer'. ${ }^{15}$ His aim was to challenge outside arbiters of his nation's place and character, and place Iceland on a par with other Christian nations in Europe. His point-counterpoint methods emphasize the errors of others, rather than Arngrimur's own vision of Iceland, though that is easily reconstructed: a harsh but not unique natural environment, and a poor but Protestant people, directly connected by history, trade and learning to Europe's mainland and its culture. This was an image that resonated with

${ }^{12}$ Ibid., 568.
13 Ibid., 572.
${ }^{14}$ Ibid., 578.
${ }_{15}$ Ibid., 553. 
some - his text was quickly translated and reprinted in Hakluyt's Principal Navigations, Voyages, Traffiques $\mathcal{E}$ Discoveries of the English Nation in 1599, and his knowledge of Icelandic sources brought him the attention and support of Danish historians. But Arngrímur's efforts to correct foreign errors about Iceland were less successful. The same sensational tales - and sometimes the same unreliable texts - continued to circulate through Europe, provoking new Icelandic rebuttals into the eighteenth century. ${ }^{16}$

Arngrimur's motives and strategies compare neatly with those of several seventeenth-century defenders of Catholic Ireland against the scurrilous descriptions of Giraldus Cambrensis (Gerald of Wales), a twelfth-century propagandist for the Anglo-Norman colonization of Ireland. Giraldus' works allegedly based on his own observations and credible testimony - had presented Ireland as a land of unnatural anomalies, its people barbarous and bestial, Christian in little but name. ${ }^{17}$ These justifications for the colonial subjugation of Ireland were equally serviceable in the sixteenth and seventeenth centuries, when his writings were excerpted in various forms, finally being printed in 1602 by the English antiquary William Camden. ${ }^{18}$ This publication then prompted a number of responses by Irish authors, rebutting Giraldus and accusing his editors of co-opting him to the cause of English Protestant rule over 'uncivilized' Ireland. Stephen White, a Salamanca-trained Irish Jesuit, wrote a refutation charging Camden with wishing to 'consolidate a greater contempt among other nations for the native Irish of past and present ages' by disseminating 'Giraldus' ancient fictions' ${ }^{\text {19 }}$; John Lynch, a schoolmaster-priest of Galway, published a systematic demolition, Cambrensis eversus (1662), noting that his 'heart sickens at the sight' when he sees 'the calumnies, of which he is the author, published in the language and writings of every nation', 'no work on the manners and customs of different nations appearing, in which his calumnious charges against the Irish are not chronicled as undoubted facts, no map engraved whose margins are not defiled with a thousand silly blunders on Ireland'. ${ }^{20}$ Both White and Lynch spent whole chapters demolishing Giraldus' authority to pronounce on Ireland: he travelled there only superficially, was ignorant of the language and of Irish writings, relied on

\footnotetext{
${ }^{16}$ Arngrímur went on to publish further polemics, particularly Anatome Blefkeniana (Hamburg, 1613) in response to Dithmar Blefkens's Islandia (Leiden, 1607); see Benediktsson, op. cit., 35-9 the limited influence of these writings. On eighteenth-century defenses of Iceland, see Karen Oslund, Iceland Imagined (Seattle: University of Washington Press, 2011), 61-78.

${ }^{17}$ Gerald of Wales, The History and Topography of Ireland, tr. by John J. O’Meara (London: Penguin, 2006).

${ }^{18}$ W. Camden, Anglica, Hibernica, Normannica, Cambrica (Frankfurt, 1602).

${ }^{19}$ White, Apologia pro Hibernia adversus Cambri calumnias (c. 1615), ed. Matthew Kelly (Dublin, 1819), v.

${ }^{20}$ John Lynch, Cambrensis eversus (St. Malo, 1662); ed. and tr. Matthew Kelly, 3 vols., (Dublin, 1848-52), I, 107. Other anti-Giraldus texts include Philip O'Sullivan Beare, Vindiciae Hiberniae contra Giraldum Cambrensem et alios (c. 1625); see Thomas O'Donnell (ed.), Selections from the Zoilomastix of Philip O'Sullivan Beare (Dublin: Stationery Office, 1960). and Geoffrey Keating, Foras Feasa ar Éirinn (c. 1634); see The History of Ireland, tr. by Edward Comyn and Patrick S. Dinneen (London: Irish Texts Society, 1901). On 'the public assertion of Irish civility', see especially J. Leerssen, Mere Irish $\mathcal{E}$ fior-ghael: Studies in the Idea of Irish Nationality (Amsterdam: John Benjamins, 1986), 291-324.
} 
hearsay from 'the very dregs of the vulgar' and 'strolling mummers, swindlers, hostlers, and penny-boys, picked up at the cross-roads and thoroughfares', took 'every blot in the character of the Irish peasant, as a means of calumniating the whole nation, ${ }^{21}$ and as a partisan witness 'recorded what should have been suppressed, and suppressed what should have been recorded' ${ }^{22}$ These polemicists marshaled evidence to prove the ancient glory of Ireland and to show that far from being scarcely human barbarians, the Irish excelled in valour, learning and piety. They cited not only classical and continental authors, but also Irish sources, particularly for Ireland's civil and ecclesiastical history - an effective innovation. ${ }^{23}$ Since Giraldus' misrepresentations were being read as evidence for the character of contemporary Ireland, his Irish confuters also moved between past and present practice. Yet they themselves only rarely cite their own present-day experience. Lynch, in a telling example, denies first-hand knowledge of barbarous popular customs: 'I, who though born in the most remote and uncivilized district in Ireland, had never once heard the slightest mention of any of them' until he read a description of Irish culture in a French book! $!^{24}$ As taught by the rhetoricians, proof by apodixis, or general experience, outweighed martyria, individual personal experience. ${ }^{25}$

Like Arngrímur, these writers were alarmed by the perpetuation of lies about their patria in print; also like him, they responded within a humanist frame of reference, relying on the rules of rhetoric and seeking erudite authority for their arguments, including that from local sources. Claiming the status of 'native' was more problematic for these polemicists than for Arngrímur's Icelanders (many were from Catholic Old English families, asserting different degrees of common ground with the Gaelic Irish). Yet, in spite of the constant insistence that 'natives', of whatever stripe, 'are better acquainted with their own affairs than strangers,' a fear of seeming partial caused all these polemicists to cede authority to others - at least those who could be cited to support their views. ${ }^{26}$ However, as with Arngrímur's commentary on Iceland, their polemics could do little to prevent Giraldus' inventions shaping lasting stereotypes of Ireland.

The Icelandic and Irish examples are very early examples of published polemic against travelers' misrepresentations retailed in a variety of genres from vernacular doggerel to scholarly compendia. Later disputes would proliferate, and would focus much more closely on accounts by individual travelers. This was in part due to an increase in the popularity and circulation of

\footnotetext{
${ }^{21}$ Lynch, op. cit., I, 327, 339.

${ }^{22}$ Ibid., III, 517.

${ }^{23}$ Keating remarks that his rebuttal rests on his reading of Irish histories, unlike his opponents, who 'did not see them, and if they had seen them, they would not have understood them', History of Ireland, 77.

${ }^{24}$ Ibid., II, 153.

${ }^{25}$ On the relative weight of apodixis and martyria see Henry Peacham, The Garden of Eloquence (London,

${ }^{26}$ Lynch, I, 285.
} 1593), 85-7. 
travel writing, but also to changes in its themes and methods. By the eighteenth century travelers in search of marketable novelty were abandoning encyclopedic description to focus more closely on 'manners and customs', understood as embodying the essence of national character. At the same time the compilation of authoritative sources on foreign countries gave way to methods based more directly on personal observation and comparison. ${ }^{27}$ These new emphases were not just a matter of fashions in travel writing, but were closely tied to the preoccupations and methods of the human sciences in the Enlightenment. However, when travelers attempted not just to describe but to account for the variety of humankind, often on highly determinist grounds, they drew indignant responses from those whom they tried to classify.

Two examples illustrate the issues involved in this new context. They both played out at about the same time, but were animated by slightly different concerns. Joseph (Giuseppe) Baretti, cited at the beginning of this article, made his targets clear in the title of his work, An Account of the Manners and Customs of Italy, with Observations on the Mistakes of some Travelers, with regard to that Country (1768). Baretti took aim at ignorant, prejudiced travelers who were 'too ready to condemn everything but what they have seen practiced at home, ${ }^{, 28}$ giving an insider's view of those aspects of contemporary Italian life and culture criticized by British travelers as degenerate, particularly in comparison to the classical past. ${ }^{29}$ Nearly a decade later, a Dalmatian citizen of the Venetian Republic, Giovanni (Ivan) Lovrich, published his 'observations' on an account of Dalmatia by an Italian traveler, the natural scientist Alberto Fortis: Osservazioni di Giovanni Lovrich sopra diversi pezzi del Viaggio in Dalmazia del Signor Abate Alberto Fortis (Venice, 1776). Here the dispute also focused on a foreign traveler's interpretation of unfamiliar 'manners and customs', in this case those of the Morlacchi, the pastoralists of the Dalmatian hinterland. The young Dalmatian took particular issue with the Italian abbé's romanticization of the Morlack frontiersmen as living in a state of nature, uncorrupted by civilization, Europe's own noble savages. ${ }^{30}$

The two polemical responses were written at the opposite ends of Europe, disputing travelers' assessments that differed radically in character, with the Italian defending his country against unfavorable opinion, and the Dalmatian

\footnotetext{
${ }^{27}$ See on this shift, in different contexts, Katherine Turner, British Travel Writers in Europe, 1750-1800 (Aldershot: Ashgate, 2001), 22-9; Friedrich Wolfzettel, Le discours du voyageur (Paris: Presses universitaires de France, 1996), 266-76; Françoise Knopper, Le regard du voyageur en Allemagne du Sud et en Autriche dans les relations de voyageurs allemands (Nancy: Presses universitaires de Nancy, 1992), 52-3.

28 Baretti, Account, 1, viii.

29 On Baretti's Account, see Cristina Bracchi, Prospettiva di una nazione di nazioni: An Account of the Manners and Customs of Italy di Giuseppe Baretti (Alessandria: Edizioni dell'Orso, 1998).

${ }^{30}$ For Fortis and Lovrich, see Larry Wolff, Venice and the Slavs: the Discovery of Dalmatia in the Age of Enlightenment (Stanford: Stanford University Press, 2001), but cf. Wendy Bracewell, 'Lovrich's Joke: Authority, Laughter and Savage Breasts in an 18th-c. Travel Polemic', Études Balkaniques 47 (2011), 224-49: http://discovery.ucl.ac.uk/id/eprint/1341903 (accessed August 2018).
} 
protesting against an apparently complimentary depiction of his countrymen. However, while the context and circumstances were different, the motives for responding and the stakes in the polemics were the same. Both took issue with the conclusions of what Baretti elsewhere called the 'fashionable characterisers of modern nations, ${ }^{31}$ protesting not just the misleading portraits of their countries, but the implication that they were somehow intrinsically different from their European neighbours, and using this difference to account for civilizational decline (in the case of the Italians) or primitive innocence (as with the Dalmatian Morlacchi).

Both the Italian Baretti and the Dalmatian Lovrich grounded their arguments in a critique of travel writing as a means to knowledge about people and places and advanced alternative views based on their own experience, both ultimately arguing that culture was relative to historically constructed circumstance. Many of their criticisms echo those of the Icelandic and Irish critics discussed above: their opponents were superficial observers whose social position did not give them access to all ranks of society; they were either mistaken, gullible, or too willing to believe the worst; they lacked sufficient knowledge of the language to understand what they saw or heard; they generalized from anecdotal evidence; they advanced inconsistent observations and arguments; they applied different standards to their own and foreign customs. Seen in comparative perspective, these complaints appear as a standard repertoire of criticisms of travelers' tales advanced by travelees (and not only by them) ${ }^{32}$

However, in these eighteenth-century cases the travelees' criticisms took added energy from the explicitly ethnographic focus and empirical claims of the travel accounts that they were attacking. Samuel Sharp, Baretti's main adversary, was the author of a travel account, Letters from Italy, describing the customs and manners of that country in the years 1765 and 1766 (1766) that bluntly rejected conventional 'descriptions of statues, churches, and pictures' as 'insipid and tiresome' and instead concentrated on everyday life as he had observed it. Although aware of the need to distinguish 'Singularities from Customs', he concluded: 'I flatter myself that I have not often been too hasty in judging the Customs and Manners of Italy'. ${ }^{33}$ Alberto Fortis, as befitting a natural scientist, was more explicit about his research and methods. He treated the 'customs of the Morlacchi' as an aspect of the natural history of Dalmatia, placing them in a separate section under this heading. He aggressively asserted his adherence to empiricism: 'I am not disposed to believe

\footnotetext{
${ }^{31}$ Joseph Baretti, A Journey from London to Genoa (London, 1770), III, 1-2.

${ }^{32}$ For early modern rhetorical devices to assert truthfulness and readers' attempts to evaluate them, Daniel Carey, 'Truth, Lies and Travel Writing' in Carl Thompson (ed.), The Routledge Companion to Travel Writing (London and New York: Routledge, 2016), 3-14, and see his 'The Problem of Credibility in Early Modern Travel', in this special issue.

${ }^{33}$ Samuel Sharp, Letters from Italy, describing the customs and manners of that country in the years 1765 and 1766 (London, 1766), 1-2.
} 
physical extravagancies unless I see them', he remarked of a tale of hairy fish in the Krin lakes, and he claimed to apply the same principles to ethnographic research among the Morlacks, writing only "what I personally saw relative to their customs and inclinations. ${ }^{34}$ As with Samuel Sharp - and many other eighteenth-century 'characterisers of modern nations' - Fortis was confident about drawing far-reaching conclusions from his observations.

Such empirical claims actively solicited responses challenging their accuracy, but neither Baretti nor Lovrich felt constrained to rebut their adversaries in a close point-counterpoint format. Baretti's Account instead presented an alternative vision of Italian society and culture arranged thematically, while Lovrich's Osservazioni used an ingenious sequence of scene-setting through travel over terrain his adversary had also visited, a thematic discussion of manners and customs, and a biography (of a Morlack bandit) that animated the interplay between custom and the contingent choices of an individual. These choices allowed full play to the travelees' insider experience and knowledge, while also facilitating attacks on their adversaries' methods and judgments.

Their criticisms centred on the pitfalls of the empirical method when applied to cultural phenomena, linguistic barriers to cultural competence, and the disadvantages of relying on local informants (let alone the dishonesty of doing so under the claim of direct personal experience). Baretti pointed out that observations made from a post-chaise were not enough to substantiate Sharp's claims to knowledge. 'Had he confined himself to the bare description of visible objects, or dealt only in representations of inn-keepers, postillions, valets-de-place, and other such people, his work might perhaps have had some veracity and some use. ${ }^{, 35}$ But since Sharp lacked the status for entry into all ranks, he had been thrown back on copying other authors or on the testimony of his servants. And worst of all, without a profound knowledge of the language, Sharp 'had not the key to our general customs and manners, which is, and never can be other, but a thorough knowledge of our language, and perfect acquaintance with our poetry' - for language was not only a medium of communication, but the point of entry into the cultural archive of literature, a means to understanding that Baretti discussed at length. ${ }^{36}$

Similarly, Lovrich noted that compiling observations of popular practices was not enough to judge a people: it was necessary to understand the context. Fortis, though he set himself up as 'a maestro of the Illyrian language', simply didn't have an adequate grasp of the language or the culture, and this led him into error. For instance, Fortis's skepticism about the 'hairy fish' was misplaced: according to Lovrich, Fortis didn't know that the same word could be used for scales as well as hair. And his claims not to believe "physical

\footnotetext{
${ }^{34}$ Alberto Fortis, Viaggio in Dalmazia (Venezia: Presso Alvise Milocco, 1774), I, 80 ('physical extravagancies'); 44 (customs of the Morlacks).

${ }^{35}$ Baretti, Account, 14-15.

${ }^{36}$ Ibid., 107.
} 
extravagancies' without seeing them were equally overblown: it was only on the basis of hearsay that Fortis could have asserted that Morlack women possessed such disgusting long breasts that they could breastfeed children over their shoulders. Lovrich disputed that Morlacks were constructed like the Africans or Greenlanders Fortis compared them to, and scoffed 'I would never have suspected that a natural historian like Fortis would have embraced this fable invented by foreigners' ${ }^{37}$ Lovrich knew some of Fortis's urban informants, and pointed out that their testimony left Fortis vulnerable to their interpretations. (He would go on, in a second pamphlet, to claim that he himself had planted the story about over-the-shoulder breastfeeding as a joke, while filling out one of Fortis's questionnaires about Morlack customs.) ${ }^{38}$ Lovrich thought it imperative to get direct first-hand testimony: 'I myself have always tried to obtain adequate information from the Morlacks themselves, and to describe the circumstances accordingly. It seems to me that this is the only way to reproduce matters in complete purity'. ${ }^{39}$ He could do this because they trusted him as a local, he claimed, implying that they did not treat the Italian scholar with the same openness.

In short, both men argued that travel experience was not a reliable basis on which to judge manners and customs. Travelers' views were always subjective and incomplete, regardless of their empiricism. They might be honest in their descriptions of experience, but this was not enough to understand and characterize a culture. Baretti put it most effectively: 'Not being able to comprehend, in the least, our peculiar way of thinking, through his utter ignorance of what he ought not to have been ignorant when he assumed the character of our censurer, he has not been able to account for what he saw or heard'. ${ }^{40}$

Was local knowledge any better? Clearly the native had an advantage in knowing the language and the culture from within, but this itself posed problems, summed up by Baretti:

A native will likewise find many difficulties in his way when he attempts to give foreigners an idea of his countrymen, because, being familiarized to all their peculiarities, he will not be able to distinguish those that will interest more than others the curiosity of a foreigner, besides that many of them will appear to him not worthy of remark; and their number may also be so great, as to make it impossible for him to commit them all to writing without risking the charge of being tedious (Baretti, Account, 188).

\footnotetext{
${ }^{37}$ Lovrich, Osservazioni, 108 (Illyrian language); 43 (hairy fish); 81 (African, European and Morlack breasts).

${ }^{38}$ Giovanni Lovrich, Lettera apologetica di Giovanni Lovrich al celebre Signor Antonio Lorgna, Colonello degl'Ingegneri, Membro di varie più illustri Accademie di Europa, in cui confutano varie censure fatte al suo libro, che à per titolo: Osservazioni sopra diversi pezzi del Viaggio in Dalmazia del signor abate Alberto Fortis (Brescia, 1777), 11; on this second reply, and Lovrich's practical joke on Fortis, see Bracewell, 'Lovrich's Joke', 236-40;

${ }^{39}$ Lovrich, Osservazioni, 111.

${ }^{40}$ Baretti, Account, 107.
} 
Beyond that, even locals could not assume that their experience, haphazardly acquired, could give a complete picture of a society. Lovrich's comments on acquiring information directly from the Morlacks indicate the need for active inquiry, despite his semi-ironic citation of Juvenal to the effect that 'one household is enough for those who wish to understand the manners of the human race'. ${ }^{11}$ The counter-travelogue that begins his Osservazioni, retracing a section of Fortis's journey to critical effect, effectively concedes the advantages of investigating even one's own territory on the ground (or underground, in the case of Lovrich's caving explorations). Baretti, too, larded his counter-descriptions of Italy's cities and provinces with comments on whether he had visited them, and for how long, or how well he knew the local dialect. Even the local knowledge of the native ethnographer had to be underpinned by travel and observation.

Nor were foreigners incapable of acquiring accurate knowledge. Baretti praised the French author of the Mémoires pour la vie de François Pétrarque (1764, by the Abbé de Sade) as the best 'master of our manners and customs [...], foreign or Italian [...] for these four hundred years', on the basis of his thorough reading of Italian literature, while Lovrich dedicated his second pamphlet to Anton Maria Lorgna, the Venetian mathematician, 'knowledgeable in the Illyrian language and our places', as someone who could adjudicate the truth about Dalmatia ${ }^{42}$ The usual superficiality and lack of cultural expertise attributed to most travel writers could not be generalized to all foreigners.

How then was one to assess the relative authority of foreign and domestic observers? The local experts were aware that they would be charged with patriotic partiality, and attempted to pre-empt such assumptions. But wasn't the foreign traveler who judged everything by the standards of home equally partial? For instance, Baretti on Sharp: 'Whatever in any other country is not done after the manner of England, you may be sure he will directly, and with surprising sagacity, find out to be wrong, abominably wrong, But though his way of arguing may prove him a very good Englishman, yet it will not entitle him to any just claims to the character of an impartial observer of other countries. ${ }^{43}$ In the end, these critics argued that no observer could have a monopoly on knowledge of a culture, but that in general the candour of the traveler was undercut by limits to his understanding, while the potential partiality of the native was outweighed by his superior access to information. This was a stronger stance than that of the Icelandic and Irish disputers, who were willing to defer to foreign authority for decorum's sake.

Both Baretti and Lovrich offered access to alternative views: it was up to their readers to judge which versions were the most credible. However, they clearly suspected that whose authority counted with an audience was very likely

\footnotetext{
${ }^{41}$ Lovrich, Osservazioni, 67.

${ }^{42}$ Baretti, Account, 109-10; Lovrich, Lettera apologetica, 1.

${ }^{43}$ Baretti, Account, 72.
} 
to be determined on other grounds than empirical evidence. After all, most of their readers were not going to be able to verify the facts on the ground. They had to choose whom to trust, but how? Historians of science have underlined the importance of social standing in early modern assessments of credibility. ${ }^{44}$ Both Baretti and Lovrich drew attention to such issues in discussing travelers' epistemological limitations, but do not seem anxious about their own status relative to that of their opponents in establishing credibility. (The difference was less marked between Sharp the well-known London surgeon and Baretti the writer and member of Dr. Johnson's circle than between Lovrich and Fortis. Lovrich the student at Padua comments on the disparity, but his apology for temerity in answering back to the distinguished scientist is framed to emphasize his courage in following a moral imperative to respond, vouching for his truth-telling.) More important, in their responses, is the probable role of cultural affinity in swaying the reader.

This was the implication of Baretti's question about the putative reception of an Italian traveler in Britain, cited at the beginning of this article. It was phrased more indirectly by Lovrich, who contrasted the way an Italian's attention to 'exotic' Morlack dress was read as 'philosophical curiosity', while the amazement of Morlack women encountering Italian women's clothes for the first time was treated as 'simplicity and foolishness'. More sarcastically, Lovrich noted the way that cultural and social advantage intertwined to confer a default authority, discussing a case where local accounts differed from those of the Italian: 'In confrontation with the Morlacks, one must sooner believe Fortis'. ${ }^{45}$ True, each travelee dedicated his work to a socially superior patron, a conventional way of asserting credibility in readers' eyes. In these transnational travel polemics, however, the salient fact is that each chose a patron from his adversary's cultural milieu: the Earl of Charlemont for Baretti, and a Venetian senator in Lovrich's case. The implication was that the cultural distance between patron and polemicist served as a guarantee of trustworthiness to an international readership.

Whose authority was trustworthy was also at the centre of the polemics that followed the publication of these travelee responses. Exchanges between Baretti and Sharp were joined by reviews and commentary from other Britons, whose assessments of Baretti focused on his identity as an Italian, whether his views were simply dismissed as those of a 'foreign adventurer' in the Critical Review or their admitted utility discounted because of Baretti's 'impudent' and 'illiberal' treatment of Sharp 'on English ground' in the London Magazine. ${ }^{46}$ The clash over authority was blunter and nastier in the Dalmatian case. Fortis feared, as he wrote to a friend, that readers "would sooner believe

\footnotetext{
${ }^{44}$ E.g. Stephen Shapin, A Social History of Truth: Civility and Science in Seventeenth-Century England (Chicago: University of Chicago Press, 1994).

${ }^{45}$ Lovrich, Osservazioni, 126; 190.

${ }^{46}$ Critical Review, 26 (1768), 17; London Magazine, 37 (1768), 224.
} 
that a Morlack should know his country without studying it better than an Italian who had occupied himself with it over several months'. His conclusion? 'One must enlighten these fools. ${ }^{47}$ His multiple replies to Lovrich show the weapons he relied upon to establish his superior authority: lists of the names of colleagues and assistants who had aided his research in Dalmatia, references to marks of professional esteem (membership of academies, publications in foreign journals, translations of his work), and most of all, vicious ridicule of his opponent. This included references to his youth and lesser social status, as well as his Dalmatian origins. This lay behind his labeling Lovrich a 'Morlack', which implied both ethnic and social distance (as Lovrich had pointed out, the term was only applied to peasants and shepherds). Fortis's characterization of Lovrich as a 'savage Morlack' was echoed by other foreign reviewers. ${ }^{48}$ But Fortis's efforts to 'enlighten the fools' effectively conceded superior authority to native inhabitants when he masqueraded under the pseudonym of a Dalmatian islander, 'Pietro Sclamer', though whom he ventriloquized 'local' testimony on behalf of the Italian's expertise and 'Dalmatian' mockery of Lovrich. ${ }^{49}$ Fortis was not entirely confident that his readers would accept his claims to social or cultural authority.

It is difficult to decide whose version of ethnographic truth won out in each case - or which side had the greatest impact on foreign attitudes to Italians or Dalmatians in the long run. In Britain, there were many sources of information on Italy and the Italians, and attitudes to Italy developed together with other, internal considerations. The most that can be said is that a less prejudiced and more appreciative British approach to Italian everyday life emerged, co-existing with long-lasting negative views of Italian 'degeneracy', though this was due less to Italian self-representation than to the accounts of sympathetic British travelers. ${ }^{50}$ In the Dalmatian case, however, Fortis's reputation and his version of the Morlacks were by far the more influential, neatly fitting a European pre-Romantic primitivism, while Lovrich's critique was forgotten or discounted. It is revealing that Fortis's remarks on extravagantly pendulous Morlack breasts were repeatedly cited as evidence for over-the-shoulder breastfeeding in subsequent scholarly literature, while Lovrich's rebuttal of this 'fable' went completely unremarked, even in Croatia. ${ }^{51}$

Juxtaposing these two cases highlights the similarities in the strategies used by the travelee-polemicists in rebutting travelers' libels against their nations

\footnotetext{
47 Žarko Muljačić, 'Iz korespondencije A. Fortisa s J. S. Wittenbachom', Radovi Filozofskog fakulteta u Zadru, 7 (1968), 113-18, apud 115.

48 Göttingische gelehrte Anzeigen, 2 (1777), 716-18; L'Esprit des Journaux (Nov. 1776) 37-44.

49 'Pietro Sclamer' [pseud. Alberto Fortis], Sermone parenetico al signor G. Lovrich (Modena, 1777); see on this Bracewell, 'Lovrich's Joke', 240-9.

${ }^{50}$ See e.g. Manfred Pfister, The Fatal Gift of Beauty: The Italies of British Travellers (Amsterdam; Atlanta, GA: Rodopi, 1996).

${ }^{51}$ E.g. in Buffon, Histoire naturelle, générale et particulière (Paris, 1798), 367; J.F. Blumenbach, De generis humani varietate nativa (Göttingen, 1795), 237; J.-J. Virey, Histoire naturelle du genre humain, 2 vols. (Paris, 1800), I, 367; Sir William Lawrence, The Natural History of Man (London, 1819; repr. 1848), 416.
} 
- ones that were common to many such encounters, but that had added leverage when applied to the ethnographic aspirations and empirical methods of much eighteenth-century travel writing. But what happened when fashions in travel writing changed? The ostensibly objective and informational "manners and customs' account demanded a response in terms of accuracy, evidence, and reliability. The increasingly popular 'sentimental' travel account of the late eighteenth century was quite different: a deliberately subjective orientation, focused on the traveler's self, with the traveler's experience represented as a means of self-revelation rather than as a source of objective information about others. ${ }^{52}$ In such accounts, the place travelled though was not so much an object of description, as a stage, or a pretext for the exercise of the author's wit, irony, or philosophical digressions. This posed new problems for travelees who objected to the way that their societies were represented. They could charge such travel writers with error, inconsistency, and inadequate access to the culture, but to what effect?

An example is furnished by Spanish reactions to a Voyage en Espagne (1784) by a minor French nobleman, Fleuriot de Langle, initially published under the pseudonym of 'Figaro' and claiming the authority of this archetypal (though fictional) Spaniard. ${ }^{53}$ This work was distinctly pre-Romantic in its stress on the traveler rather than the journey. The preface to the first edition made this one of its merits: 'Never has anyone painted himself better in a work $[\ldots]$ one believes oneself to have spent ten years with him', while the revised edition praised Fleuriot as a successor to Laurence Sterne, adding 'This is not a Journey to Spain that you read, it is the author's own journey, as its title declares; it is about himself, all about himself; you will find more here than Spain ${ }^{54}$ It was advertised as a deliberately anti-empirical travel account: 'We recognize without difficulty that the author has sought nothing, expected nothing, retained nothing, and that whatever he says, he feels, thinks, and releases as a sigh [...] Here, his disorder, negligence, incoherent or singular ideas, are wisdom; there, his errors are a virtue'. ${ }^{55}$ The preface to the English edition correctly remarked, 'If you want very accurate, learned, philosophical, and political Travels; [...] throw this Journey aside. ${ }^{56}$ Throughout the text, knowledge derived from the traveler's experience is presented as trivial or

${ }^{52}$ For surveys of the Romantic travel account, see e.g. Roger Cardinal, 'Romantic Travel', in Roy Porter (ed.), Rewriting the Self: Histories from the Renaissance to the Present (London: Routledge, 1997); Friedrich Wolfzettel, Ce désir de vagabondage cosmopolite: Wege und Entwicklung des französischen Reiseberichts im 19. Jahrhundert (Tübingen: Max Niemeyer Verlag, 1986).

53 'Figaro' [pseud. Jean Marie Jérôme Fleuriot de Langle], Voyage en Espagne (Saint-Malo, 1784; 3rd rev. edn. [Paris], 1785), multiple subsequent editions and translations, including A Sentimental Journey through Spain (London, 1788). References are to the first French edition except where noted. The character of Figaro was created by the French playwright Beaumarchais in The Barber of Seville (1773), though he drew on the Commedia dell'arte figure Brighella.

${ }^{54}$ Fleuriot, Voyage, viii; Voyage en Espagne (3rd rev. edn. [Paris], 1785), I, vii.

55 Voyage, iii.

${ }^{56}$ Sentimental Journey, iii. 
bathetic, satirizing the claims of empiricism (e.g. detailed observations on the 'fat legs' of a landlady). Its ironic treatment of political and social circumstances could be - and was - read as an indirect attack on ancien régime France (behind its version of Catholic, Bourbon Spain lay a sort of exaggerated France). The picture of Spain that the author sketched was validated more by artlessness than by any pretension to empiricism. Yet the book is also full of circumstantial detail about Spanish customs and institutions, recycling well-established clichés of pride, indolence, ignorance and fanaticism, and its picture of Spain is presented as accurate: 'However bitter may be the truths he utters, the author loves the Spaniards, and he renders them justice'. ${ }^{57}$ Whatever his ulterior targets may have been, Fleuriot's book operated at Spain's expense.

From Madame d'Aulnoy's Relation du voyage d'Espagne (1691) onwards, foreign accounts of Spain, for the most part written on ostensibly objective and empirical lines, had prompted Spanish denunciations of libel addressed to a domestic readership. But it was Fleuriot's Voyage that received a direct reply in French, published by a 'véritable Figaro', none other than Spain's ambassador in Paris, the Count of Aranda. ${ }^{58}$ Why should this sentimental and facetious text have received the dignity of a public denunciation? Aranda, like other travelee polemicists before and afterwards, cited the damage done by the circulation of lies in print: 'often a fable that one would not listen to in conversation, is received without contradiction when found in a book' ${ }^{59}$ One contributor to a scholarly edition of Fleuriot's Voyage believes that Aranda was forced to respond only because of Fleuriot's impudent praise of his (imputed) religious tolerance and anti-clericalism. ${ }^{60}$ Contemporary references, however, suggest that other Spanish readers were also infuriated by Fleuriot, objecting to his derisive mockery as much as to his stereotyped calumnies. ${ }^{61}$

But how to refute such a text? Much of the approach is already familiar. Aranda replied as a Spaniard, claiming both the knowledge and the responsibility to defend Spain, but rejecting the role of a Don Quixote 'breaking lances' for his country. ${ }^{62}$ His aim was 'to show the ignorance and folly of the author, to review his ineptitudes and lies, accompanying him all the while'. ${ }^{63}$

\footnotetext{
${ }^{57}$ Fleuriot, Voyage, xiii-xiv.

58 'Le Véritable Figaro' [pseud. Pedro Pablo Abarca de Bolea, conde de Aranda], Dénonciation au public du voyage d'un soi-disant Figaro en Espagne (London [Paris], 1785); see also J. Benimeli, El conde de Aranda y su defensa de España: refutación del Viaje de Figaro a España (Madrid: Universidad de Zaragoza, 1972).

${ }^{59}$ Aranda, Dénonciation, vii-viii.

${ }^{60}$ Henri Duranton, 'La polémique avec l'ambassadeur d'Espagne', Voyage de Figaro en Espagne, Robert Favre ed. (Saint-Étienne: Université de Saint-Étienne, 1991), 90.

${ }^{61}$ See e.g. Antonio Ponz, Viage fuera de España (Madrid, 1785), I, ii (on foreign mockery and ridicule), xxxviii (Figaro's 'ravings'), lxi (his 'nonsense').

${ }^{62}$ A piquant irony: the Dénonciation was in fact written in collaboration with a Frenchman, Aranda supplying 'the canvas and the justifications', the Frenchman elaborating the text and polishing the wit; see Benimeli, Conde de Aranda, 158-61.

${ }^{63}$ Dénonciation, 3.
} 
And so he did, in point-counterpoint form, refuting falsehoods, pointing out contradictions, asking whether specific defects were unique to Spain, and emphasizing Spanish reforms and achievements. The defense makes clear that the French author's essentialization of Spanish difference is one of the main issues at stake: 'Happily in Spain, in this regard, it [religious belief] is as everywhere else, according to our traveler, and the Spaniards resemble, at least in this point, the rest of humanity; that is something, anyway'. ${ }^{64}$

Aranda attacked Fleuriot's portrayal using much the same arguments as other travelee critics: inaccuracy, generalization from anecdote, malicious misrepresentation, nothing but low company as his sources, hearsay and plagiarism; and he contradicted his adversary on the basis of his own native experience and knowledge. Aranda seems to have seen the limits to such arguments when applied to frivolous ridicule or the use of Spain as a proxy for criticisms whose point lay elsewhere: 'There are some absurdities so gross that it is unnecessary to refute them. [...] It is beneath the dignity of a Spaniard to respond ${ }^{65}$ Aranda nonetheless did try to address such absurdities, decrying Fleuriot's nonsense, unraveling his hidden meanings, and attempting to show how the author's wit misrepresented reality. Thus, for instance, on Fleuriot's attack on Philip IV's callousness towards his subjects: 'is this not an indirect criticism of some other princes? This little ruse would be quite in keeping with the character of the false Figaro'. ${ }^{66}$ Similarly, the Dénonciation consistently pointed out the ways in which Fleuriot's reliance on paradox or bathos necessarily led to exaggeration and inaccuracy. This was beside the point, however, since the entertainment value of the French Figaro's style lay in its audacious extravagance. A step-by-step factual rebuttal could scarcely counter frivolous fabrications: this was a mismatch between the tools of empirical criticism and the discursive practices of the pre-Romantic travel text.

Aranda's denunciation had the opposite effect to that intended, advertising the Voyage and encouraging the publication of a third, expanded, edition, this time under Fleuriot's own name. Aranda recognized as much in a second denunciation, an open letter in the Journal de Paris, regretting that his earlier work had not met with more success: 'a commentary rarely amuses and, what is more, a commentary tends to disabuse its readers, and there are those things about which we do not care to be disabused. [...] The truth, when it is neither pleasant nor piquant, is too ordinary for most readers' ${ }^{67}$ Rather than continuing to rebut Fleuriot, Aranda complained to the French Foreign Minister about the consequences for diplomatic relations, and succeeded in having the book publically burnt. However, as Fleuriot had anticipated, 'the

${ }^{64}$ Ibid., 124.

65 Ibid., 71.

${ }^{66} \mathrm{Ibid}$., 31; this was censored: originally Aranda wrote 'an indirect criticism of some other prince, whom he did not dare to attack openly?'.

${ }^{67}$ Le Véritable Figaro [Aranda], Journal de Paris, 318 (14 Nov 1785), 1309-11, apud 1310. 
public loves burnt books', and this made it more marketable: the English translation even advertised that the Paris edition had been 'burnt by the common Hangman'. 68

However subjective and extravagant, Fleuriot's Voyage purported to show an observed reality. Aranda argued that the false Figaro required a reply substantiated by experiential evidence, from an author capable of 'calculating the accuracy and truth of his observations', lest he deceive credulous readers. ${ }^{69}$ He was seconded by other Spanish critics, including the enlightened reformer Antonio Ponz, who argued that failing to counter the lies of 'an imposter like Figaro' made space for others 'who, copying one another, and adding nonsense to nonsense, have filled Europe with detestable books, replete with a thousand falsehoods and insults against our nation'. Ponz followed the same pattern of step-by-step quotation and response, but for domestic readers. ${ }^{70}$ Both men asserted the duty and the expertise, as Spaniards, to respond. Elsewhere, however, readers confronting Fleuriot's Spanish farrago were unconvinced that an empirical rebuttal was necessary or effective. The critic Friedrich Melchior Grimm promptly dismissed the book as 'a tissue of absurd falsehoods' (though he did agree that Spanish prejudices had prevented them from sharing the benefits of enlightened progress). However, he added that Aranda's 'perpetual rebuttal' was 'not as amusing as the lies he sought to destroy', and had only promoted the book. ${ }^{71}$ British reviewers were slightly more receptive to the French Figaro, in that the translation of Fleuriot's work was thought to offer 'some amusement and some information', but here too the Spanish reaction was seen as counterproductive, even given Fleuriot's caricature of the country and its people. ${ }^{72}$ In the case of the frivolous and subjective pre-Romantic travel account, one is left with conclusion that experiential knowledge combined with offended patriotism was in fact an impediment to effective refutation. Sober empirical criticism, even when validated by native experience, could do little when a traveller's calumnies were wrapped in wit and delivered as entertainment.

The travelee polemics analysed here highlighted the ways that travelers articulated, interpreted and used their experiences. The travelees were quick to point out inconsistencies that suggested that travelers had not represented their experiences accurately. But what was at issue in the travelee responses

\footnotetext{
${ }^{68}$ Fleuriot, Voyage en Espagne (3rd rev. edn., [Paris], 1785), II, 13; Sentimental Journey, title page.

${ }^{69}$ Aranda, Dénonciation, vii.

${ }^{70}$ Ponz, Viage fuera de España, I, lxi. See e.g. Antonio Ponz, Viage fuera de España (Madrid, 1785), I, ii (on foreign mockery and ridicule), xxxviii-lxii (extracting and rebutting Figaro's 'ravings').

${ }^{71}$ Friedrich Melchior Freiherr von Grimm, Correspondance littéraire, philosophique et critique de Grimm et de Diderot (Paris, 1830), XII, 453-4.

${ }^{72}$ European Review and London Magazine, 10 (October 1786), 262.
} 
was not the travelers' honesty (the problem of the 'travel liar'). The key criticism was that of the travelers' epistemological limitations. Even where they had represented their experiences truthfully, the character of those experiences prevented them from drawing credible, reliable conclusions about the character of foreign societies and cultures. Their travels were brief and superficial, they lacked adequate linguistic or social access to society as a whole, so they were forced to argue from anecdotal evidence and trifling observations, and they were easily deceived or misled since they had no means of assessing their informants' credibility. In short, the travelers lacked the cultural competence to interpret their experiences correctly.

In turn, the travelees discussed here advanced alternative views of their societies, presenting them as more authoritative and reliable. Direct experience underpinned their interpretations too, but their status as cultural insiders, with superior access and understanding, bolstered its value. True, that same insider status could disqualify their views, if patriotically prejudiced. They downplayed this possibility, but also argued that it was cancelled out by the prejudices of the foreign traveler who judged everything against a familiar domestic standard. They supplied the same extrinsic evidence of their authority as foreign travelers: dedications, educational or professional qualifications, references to classical authority or other travel texts (including those by foreigners whose opinions coincided with their own). Their strictly textual journeys - following their adversaries point by point through an account - were frequently complemented by references to their own physical travels through their native land. In short, these travelees legitimated their counter-narratives according to the same standards and protocols as their opponents, even to the extent of underlining travel as a crucial means to the experience needed for knowledge.

Many travelees deployed a point-counterpoint rebuttal, tethering their responses closely to their opponents' texts. However, dogged shadowing of the foreign traveler was not crucial to success, and could be a rhetorical disadvantage, encouraging pettiness and pedantry. The travelees' attacks were most telling when they corresponded not to the format but to the theories and methods of knowledge of their opponents. Demonstrating a foreign traveler's dependence on hearsay was particularly damning when that observer prided himself on autopsy; correcting a linguistic error undermined an interpreter most effectively when he had claimed mastery of a language and culture. But these tactics only succeeded when they coincided with the aims and methods of their adversaries. Sober detection and rectification of extravagant flights of fancy - however much patriotic sensitivity demanded it - could be worse than useless if they laid the critic open to charges of pomposity or dullwittedness.

These travelees bitterly resented the suggestion that they were in any essential way civilizationally different from their adversaries. Some went so far as to stress, in response, the distance between themselves and the non-European cultures that travelers compared them to. Their claims to the 
epistemological weight of their own insider experience did not equate to claims that 'native anthropology' leads to a fundamentally different, more authentic portrayal of a people, free of the hegemonic assumptions of 'Western' outsider approaches. ${ }^{73}$ Nor were they in any position to use their experiences to undermine the normative character that their adversaries claimed for their own versions of 'European civilization', unlike for instance early modern Spanish American critics of foreign travel accounts. ${ }^{74}$ These travelees utterly rejected the notion that they should be characterized in terms of radical alterity, arguing instead for the commensurability of nature, of experience, and of European cultures. While they presented themselves as having greater access to and empathy with the societies they defended, ultimately they argued that their accounts of experience and those presented by others should be judged by the same criteria.

Behind the travelees' arguments, however, lay a suspicion that readers were more likely to trust their own co-nationals on the basis of cultural affinity, than they were likely to accept the travelees' experiential authority. Was this true? Certainly none of the travelee responses silenced their adversaries, and none had a determining effect on wider European attitudes to their societies. Fantasies about Iceland and Ireland continued to circulate regardless of the responses of their defenders, even if their new sources were also given weight in learned circles. British views of Italy were long divided between disgust and approbation, but they were shaped more by British writers than by Baretti or other Italian cultural interpreters. Lovrich's biography of a Morlack bandit was excerpted and re-circulated across Europe but, ironically, in the service of an exoticizing image of Dalmatia, while Fortis's views received a respectful hearing in Croatia as well as in Europe-wide scholarship. ${ }^{75}$ Readers laughed at Fleuriot's Figaro (both recognizing and reinforcing its clichés about Spain), more titillated than enlightened by Spanish censure of the work. Whose experience actually counted with readers appears to have been affected by other criteria than the evidence adduced by early modern travelees. Arguing from experience could only get you so far, when confronting an epistemological decorum whose boundaries were set by social status, cultural proximity, and the conventions of genre.

University College London

\footnotetext{
${ }^{73}$ See e.g. Emiko Ohnuki-Tierney, “Native”Anthropologists', in American Ethnologist, 11 (1984), 584-6; for a critique of these positions in contemporary anthropology, Takeyuki Tsuda, 'Is Native Anthropology Really Possible?' Anthropology Today, 31 (2015), 14-17.

${ }^{74}$ Jorge Cañizares-Esguerra,'Postcolonialism avant la lettre? Travelers and Clerics in Eighteenth-Century Colonial Spanish America', in Mark Thurner and Andrés Guerrero (eds.), After Spanish Rule: Postcolonial Predicaments of the Americas (Durham: Duke University Press, 2003), 89-110.

${ }^{75}$ Bracewell, 'Lovrich's Joke'; for the afterlife of Lovrich's biography of the bandit Sočivica, see Andrei Pippidi, 'Naissance, renaissances et mort du "Bon Sauvage": à propos des Morlaques et des Valacques', Hommes et idées du Sud-Est européen à l'aube de l'âge moderne (Paris and Bucharest: Éditions du CNRS; Editura Academiei, 1980), 1-23.
} 